\title{
Pentagons in Medieval Sources and Architecture
}

\author{
Krisztina Fehér ${ }^{1}$ (D) $\cdot$ Brigitta Szilágyi ${ }^{1}$ - Attila Bölcskei ${ }^{1} \cdot$ Balázs Halmos $^{1}$
}

Published online: 8 July 2019

(c) The Author(s) 2019

\begin{abstract}
A range of entirely different pentagon approximations are known from textual and graphic sources related to the architecture of the Middle Ages. Analysis of the mathematical logic behind them highlights the scientific knowledge of master masons who directly calculated constructional methods according to their practical needs. From the examination of these pentagon approximations, their mathematical features, such as the initial data of the construction or precision of side lengths and angles, the range of architectural design problems they would have been able to solve can be determined. This paper provides an accurate comparison of mathematical and geometrical features of pentagon constructions from medieval sources, studying their applicability from an architectural aspect.
\end{abstract}

Keywords Gothic $\cdot$ Geometry · Geometric analysis · Pentagon

\section{Introduction}

The design methods of medieval architects represent a topic of countless aspects. Although, due to its rich bibliography, several questions have been answered with highly significant results, new questions keep emerging. It is clear that the most frequent simple geometric forms that master masons used during their design work were the regular triangle and the square. Besides these, considering its deep and fundamental symbolic meanings, the pentagon may also have played an important role in medieval culture (Ginovart et al. 2018: 159). However, the architectural

Krisztina Fehér

feher.krisztina@eptort.bme.hu

Brigitta Szilágyi

szilagyi@math.bme.hu

Attila Bölcskei

Bolcskei.Attila@ybl.szie.hu

Balázs Halmos

halmos@eptort.bme.hu

1 Múegyetem Rakpart 3. K. 282, Budapest 1111, Hungary

Dirkhäuser 
application of this form is not nearly as obvious as, for instance, geometric figures of even number of sides. The occurrence of pentagons in medieval architecture tends to be considered as rare; scholars have suggested that its correct geometrical construction was unknown among artists or architects until the early 16th century, despite being known in liberal arts education (Meckseper 1983: 34-35; Hoppe 1995: 143). Assessing the frequency of its architectural application is not as simple as it seems. Besides the several methods, the figure was used in different stages of design, which will be described within the scope of this paper, with pentagonal forms detected in medieval buildings throughout Europe (for example, England, France, Germany, Bohemia, Hungary) from the Early Middle Ages to Late Gothic times (Fehér et al. 2018a, b; Pentagons: 305-315). The correct construction of the regular pentagon was commonly known (Scriba et al. 2015: 62-63; Corry 2013), but seems to have been rather ignored in the architectural practice of the Middle Ages (Kidson 2008: 10). According to the few remaining medieval graphic sources of architecture, master masons had invented or learnt methods for the geometrical approximation of the figure. Scholars have already proposed several interpretations of the steps of geometric construction methods preserved on drawings (Meckseper 1983; Hoppe 1995).

However, beyond the theoretical approach, the correspondence of pentagonal approximations and adequate architectural examples where these methods may have been applied in practice is hardly discussed. In this paper, a mathematical analysis of the accuracy and additional features of the approximations is carried out, as well as the detailed examination of their correlation with relevant medieval constructions. As a consequence of the limited original sources on the construction of the period, it is easy to speculate; however, the research tries to confine itself to impartial examination and stay within the field of hypothesis.

The number 5 and pentagon have a broad symbolic background, and it is relevant to mention some fundamental historical interpretations that help to highlight the richness of this topic. Five is considered as the number of human needs, redemption and grace, referring to the Five Holy Wounds of Christ (John 19:34, John 20:24), or the Wise and Foolish Virgins in a parable of Jesus (Matthew 25). It appears in the five curtains, bars and pillars of the Tabernacle (Exodus 26), the altar of which was also five cubits long and five cubits wide (Exodus 27). According to Liber Manualis of the Frankish countess Dhuoda, from the 9th century, five meant the five clever virgins or the five senses of the body (Bondurand 1887: 33). Five has also been related to the quinta essentia in alchemy, and the Pythagoreans who chose the pentagram as their symbol, associating it with the fifth element of ether (Fletcher 2006: 83). According to Macrobius Ambrosius Theodosius, the number five represented the supreme God and the totality of the Universe (Ginovart et al. 2018: 159).

The topic of the medieval architectural applications of the pentagon has been commented on by many authors. Hans Hahnloser, in his critical facsimile of the sketchbook of Villard de Honnecourt, described the figure of the 'pentagonal tower' (Hahnloser 1972: 124). It was Cord Meckseper who focused on the medieval problematic of this form and provided interpretations regarding the geometrical clues of pentagonal approximations occurring in medieval sources 
(Meckseper 1983). While a brief outline of this question was summarised in the inclusive works of medieval design and constructional methods (Müller 1990: 108-110, Hiscock 2000: 191-193), Robert Bechmann and Jean Wirth further examined Villard's portfolio (Bechmann 1991: 146-148, Wirth 2015). Partially based on the results of Meckseper, László Hoppe went on to discuss the detailed interpretation of medieval pentagon approximations, adding further alternative speculative methods (Hoppe 1995). Disputing some of the clues suggested by Meckseper and Hoppe, authors of the present study have proposed alternative interpretations for the figure of the portfolio of Villard de Honnecourt (Fehér et al. 2018a, b; Golden Ratio: 42-45) and the pentagon of Master WG. In addition, this paper provides a series of architectural examples containing pentagonal forms highlighting that its role in the design process of medieval masters was much richer than it is currently considered (Fehér et al. 2018a, b Pentagons: 300-303, 305-314). More recently, the new edition of the precious Collection of Prints and Drawings of the Academy of Fine Arts, Vienna by Johan Böker also contains new interpretations of plans containing pentagonal drawings (Böker 2005: 395).

\section{Pentagon Approximations and Actual Architectural Situations}

\section{Pentagonal Tower in the Sketchbook of Villard de Honnecourt (No. 1 in Table 1)}

On folio 21 recto of the well-known sketchbook of the 13th-century Picardian master, the diagram of a pentagonal tower with the inscription 'par chu portrait om one/toor a chinc arestes' [ 'By this (means) one represents a tower with five edges.' translated by Barnes 2009: 148] was dedicated to a successor of Villard called Hand IV by Barnes (2009: 13, 147-148). The drawing is so roughly depicted that it is even questionable if Hand IV could have been an architect as, among other figures, he has copied the pentagon from another folio with basic mistakes (Barnes 2009: 13; Branner 1960: 96). Consequently, the schematic nature of the sketch makes it difficult to reconstruct the actual logic behind the pentagonal construction. It is plausible that the method is based on the rotation of right angles; however, it is curious how the crucial exterior angle of the pentagon of $72^{\circ}$, or any connecting angles, were produced. According to Meckseper's suggestion that was also shared by Bechmann, Wirth and Hoppe, the 3-1 ratio was used for the approximation of tangent $72^{\circ}$ (Meckseper 1983: 31-32, Bechmann 1991: 146-147, Wirth 2015: 186-187, Hoppe 1995: 144-146). Despite that no blind lines can be detected, which could verify the application of this numerical proportion, it is a feasible suggestion although, a correction could be proposed concerning the direction of the operation: the drawing has more likely been worked out counterclockwise with fewer steps than speculated by Meckseper (Fehér et al. 2018a, b Golden ratio: 44-45) (Fig. 1). The drawing does not represent the final step of the method; thus, the pentagon itself is incomplete. It is obvious that the sketch was carried out rather roughly by hand without measuring the actual distances and angles. With the proper completion, it 
Table 1 Collection of results of the investigated approximating constructions according to accuracy

\begin{tabular}{|c|c|c|c|c|c|c|c|c|c|c|}
\hline Method & $\begin{array}{c}\text { Initial data of } \\
\text { the construction }\end{array}$ & $\begin{array}{c}\text { Mathematical } \\
\text { correlation behind } \\
\text { the construction }\end{array}$ & Figure & $\begin{array}{c}\text { Ratio of the side } \\
\text { lengths }\end{array}$ & $\begin{array}{c}\text { Angles (in } \\
\text { degrees) }\end{array}$ & $\begin{array}{l}\text { Level of } \\
\text { accuracy }\end{array}$ & $\begin{array}{c}\text { Maximum } \\
\text { angle } \\
\text { deviation }\end{array}$ & $\begin{array}{c}\text { Circumse } \\
\text { ribed } \\
\text { circle }\end{array}$ & \begin{tabular}{|c|}
$\begin{array}{c}\text { Central angle } \\
\text { belonging to } \\
\text { sides (in } \\
\text { degrees) }\end{array}$ \\
\end{tabular} & $\begin{array}{l}\text { Level of } \\
\text { accuracy }\end{array}$ \\
\hline $\begin{array}{l}\text { Regular } \\
\text { pentagon (the } \\
\text { ideal case) }\end{array}$ & $\begin{array}{l}\text { Radius of the } \\
\text { circumcircle }\end{array}$ & Golden Ratio & & $1: 1: 1: 1: 1$ & 108 & $100 \%$ & $0 \%$ & yes & 72 & $100 \%$ \\
\hline \multicolumn{11}{|c|}{ Groupe 1: Solutions without a circumscribed circle } \\
\hline \begin{tabular}{|l|} 
1. Pentagonal \\
tower in the \\
sketchbook of \\
Villard de \\
Honnecourt
\end{tabular} & Side length & $\begin{array}{l}\text { Approximation of the } \\
\operatorname{tg} 72^{\circ} \text { by a numerical } \\
\text { ratio. }\end{array}$ & & $1: 1: 1: 1: 1.02615$ & $\begin{array}{l}108.435 \\
(3 \text { times); } \\
107.348 \\
(2 \text { times) }\end{array}$ & $\begin{array}{l}100.402 \% \\
(3 \text { times); } \\
99.396 \% \\
(2 \text { times) }\end{array}$ & $0.604 \%$ & no & - & - \\
\hline \begin{tabular}{|l|} 
Pentagon \\
construction \\
of Mathes \\
Roriczer's \\
Geometria \\
Deutsch
\end{tabular} & Side length & $\begin{array}{l}\text { A certain series of } \\
\text { steps that is drawn by } \\
\text { the same opening of } \\
\text { the compass. }\end{array}$ & & $1: 1: 1: 1: 1$ & $\begin{array}{c}108.366 \\
(2 \text { times); } \\
107.038 \\
(2 \text { times); } \\
109.192 \\
(1 \text { time })\end{array}$ & $\begin{array}{l}100.338 \% \\
(2 \text { times); } \\
99.109 \% \\
(2 \text { times); } \\
101.103 \% \\
\text { (1 time) }\end{array}$ & $1.103 \%$ & no & - & - \\
\hline \begin{tabular}{|l|}
3. \\
Diagram $A$ of \\
the Vienna \\
Collection of \\
Prints and \\
Drawings \\
\end{tabular} & Side length & $\begin{array}{l}\text { Approximating the } \\
\text { right pentagon from } \\
\text { above and below. }\end{array}$ & & $\begin{array}{l}\text { 1:1:1:1.05329: } \\
\quad: 1.05329\end{array}$ & $\begin{array}{c}103.609 \\
(2 \text { times); } \\
110.147 \\
(1 \text { time); } \\
111.318 \\
(2 \text { times }) \\
\end{array}$ & $\begin{array}{l}95.934 \% \\
(2 \text { times); } \\
101.987 \% \\
(1 \text { time); } \\
103.072 \% \\
(2 \text { times) }\end{array}$ & $4.066 \%$ & no & - & - \\
\hline \begin{tabular}{|l|}
4. \\
Diagram $B$ of \\
the Vienna \\
Collection of \\
Prints and \\
Drawings \\
\end{tabular} & Side length & $\begin{array}{l}\text { The initial steps are } \\
\text { clear using circles of } \\
\text { a radius equal to the } \\
\text { side length of the } \\
\text { pentagon for seeking } \\
\text { the upper side points. }\end{array}$ & & $1: 1: 1: 1: 1$ & $\begin{array}{c}108.435 \\
(2 \text { times); } \\
106.856 \\
(2 \text { times); } \\
109.417 \\
(1 \text { time })\end{array}$ & $\begin{array}{l}100.402 \% \\
(2 \text { times); } \\
98.940 \\
(2 \text { times); } \\
101.312 \\
(1 \text { time })\end{array}$ & $1.312 \%$ & no & - & - \\
\hline \begin{tabular}{|l|}
$\mathbf{1 0 .}$ \\
Hypothetic \\
construction \\
with ratio \\
$10: 17$ (not in a \\
circle)
\end{tabular} & $\begin{array}{l}\text { Height length of } \\
\text { the pentagon }\end{array}$ & $\begin{array}{l}\text { Construction of the } \\
\text { side from the height } \\
\text { of the pentagon by a } \\
\text { numerical ratio } \\
\text { (approximation of the } \\
\sin 36^{\circ} \text { ). }\end{array}$ & & $\begin{array}{l}\text { 1:1:1.00191:1: } \\
\quad: 1.00191\end{array}$ & $\begin{array}{l}107.936 \\
(1 \text { time); } \\
108.016 \\
\text { (4 times) }\end{array}$ & $\begin{array}{l}99.940 \% \\
(1 \text { time }) \\
100.014 \% \\
(4 \text { times) }\end{array}$ & $0.060 \%$ & no & - & - \\
\hline \multicolumn{11}{|c|}{ Groupe 2: Solutions with a circumscribed circle } \\
\hline \begin{tabular}{|l|}
. \\
Diagram $C$ of \\
the Vienna \\
Collection of \\
Prints and \\
Drawings \\
\end{tabular} & Side length & $\begin{array}{l}\text { A certain series of } \\
\text { steps leading from } \\
\text { the side length to the } \\
\text { radius of the } \\
\text { circumcircle by } \\
\text { curves. }\end{array}$ & & 1:1:1:1:1.08853 & $\begin{array}{c}109.469 \\
(3 \text { times) } \\
105.796 \\
(2 \text { times) }\end{array}$ & $\begin{array}{l}101.360 \% \\
(3 \text { times); } \\
97,959 \% \\
\text { (2 times) }\end{array}$ & $2.041 \%$ & yes & $\begin{array}{c}70.531 \\
(4 \text { times); } \\
77.876 \\
(1 \text { time })\end{array}$ & $\begin{array}{c}97.959 \% \\
\text { (4 times); } \\
108.161 \% \\
(1 \text { time) }\end{array}$ \\
\hline $\begin{array}{l}7 . \\
\text { Pentagon in } \\
\text { the sketchbook } \\
\text { of Master WG }\end{array}$ & $\begin{array}{l}\text { Radius of the } \\
\text { incircle and the } \\
\text { circumcircle, } \\
\text { derived from a } \\
\text { pre-existing } \\
\text { square and } \\
\text { octagon. }\end{array}$ & $\begin{array}{l}\text { The proportion of the } \\
\text { radius of the } \\
\text { circumcircle and the } \\
\text { incircle is set by a } \\
\text { certain division of the } \\
\text { half diagonal of the } \\
\text { square with an } \\
\text { inscribed octagon. }\end{array}$ & & $\begin{array}{l}1: 1: 1.12131: 1: \\
\quad: 1.12131\end{array}$ & $\begin{array}{c}107.031 \\
(4 \text { times); } \\
111.874 \\
(1 \text { time })\end{array}$ & $\begin{array}{c}99.102 \% \\
(4 \text { times); } \\
103.587 \% \\
(1 \text { time) }\end{array}$ & $3.587 \%$ & yes & $\begin{array}{c}68.125 \\
(3 \text { times); } \\
77.812 \\
(2 \text { times) }\end{array}$ & $\begin{array}{l}94.618 \% \\
(3 \text { times); } \\
108.072 \% \\
(2 \text { times) }\end{array}$ \\
\hline \begin{tabular}{|l|}
8. \\
Construction \\
with Fibonacci \\
numbers 5 and \\
8
\end{tabular} & $\begin{array}{l}\text { Radius of the } \\
\text { circumcircle }\end{array}$ & $\begin{array}{l}\text { Approximation of the } \\
\text { Golden Ratio by } \\
\text { neighbouring } \\
\text { members of the } \\
\text { Fibonacci sequence }\end{array}$ & & 1:1:1:1:0.98435 & $\begin{array}{l}107.739 \\
(3 \text { times }) \\
108.391 \\
(2 \text { times })\end{array}$ & $\begin{array}{l}99.758 \% \\
(3 \text { times); } \\
100.362 \% \\
(2 \text { times) }\end{array}$ & $0.362 \%$ & yes & $\begin{array}{c}72.261 \\
(4 \text { times }) \\
70.957 \\
(1 \text { time })\end{array}$ & $\begin{array}{l}100.362 \% \\
(4 \text { times); } \\
98.551 \% \\
\text { (1 time) }\end{array}$ \\
\hline \begin{tabular}{|l|} 
9. Hypothetic \\
construction \\
with ratio \\
$10: 17$ (in a \\
circle) \\
\end{tabular} & $\begin{array}{l}\text { Radius of the } \\
\text { circumcircle }\end{array}$ & $\begin{array}{l}\text { Approximation of the } \\
\cos 54^{\circ} \text { by a } \\
\text { numerical ratio. }\end{array}$ & & $1: 1: 1: 1: 0.99617$ & $\begin{array}{l}107.936 \\
\text { (3 times); } \\
108.095 \\
\text { (2 times) }\end{array}$ & $\begin{array}{l}99.941 \% \\
(3 \text { times); } \\
100.088 \\
\text { (2 times) }\end{array}$ & $0.088 \%$ & yes & $\begin{array}{c}72.064 \\
\text { (4 times); } \\
71.744 \\
(1 \text { time) }\end{array}$ & $\begin{array}{c}100.089 \% \\
(4 \text { times); } \\
99.644 \% \\
(1 \text { time) }\end{array}$ \\
\hline \multicolumn{11}{|c|}{ Groupe 3: Non-ruler-and-compass solution } \\
\hline $\begin{array}{l}\text { 6. Pentagonal } \\
\text { construction } \\
\text { in the } \\
\text { sketchbook of } \\
\text { Hans Hammer }\end{array}$ & $\begin{array}{l}\text { Radius of the } \\
\text { circumcircle }\end{array}$ & $\begin{array}{l}\text { Dividing the circle } \\
\text { into five parts by } \\
\text { using a twine the } \\
\text { length of } 5 / 4 \text { of the } \\
\text { radius. } \\
\text { (Approximation of } \\
\text { the } \pi \text { with } 25 / 8 \text {.) }\end{array}$ & & 1:1:1:1:1.02285 & $\begin{array}{c}108.380 \\
(3 \text { times); } \\
107.429 \\
(2 \text { times })\end{array}$ & $\begin{array}{l}100.351 \% \\
(3 \text { times); } \\
99.471 \% \\
\text { ( } 2 \text { times) }\end{array}$ & $0.529 \%$ & yes & $\begin{array}{c}5 / 4 \\
\text { radian } \approx 71.619 \\
\text { (4 times); } \\
2 \pi-5 \\
\text { radian } \approx 73.524 \\
(1 \text { time })\end{array}$ & $\begin{array}{c}99.471 \% \\
(4 \text { times); } \\
102.116 \% \\
(1 \text { time) }\end{array}$ \\
\hline
\end{tabular}

would show a rather distorted pentagon. Following the steps around the polygon, the missing last angle (at A) and side (AE) would differ slightly from the other angles and sides; however, the sketch shows a much larger divergence. 

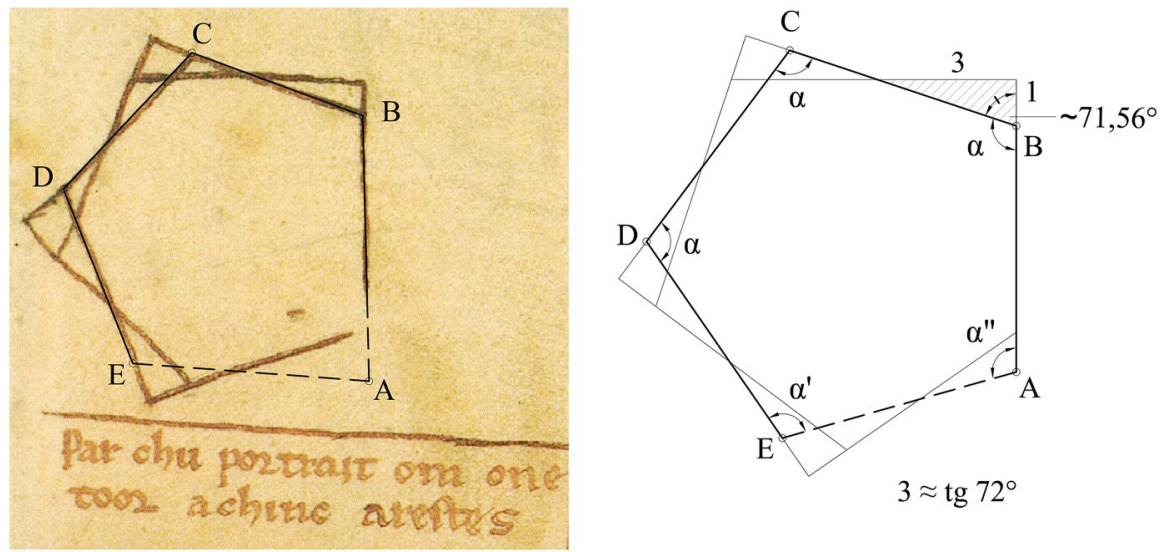

Fig. 1 Another suggestion for the algorithm of the pentagonal construction in the portfolio of Villard de Honnecourt (authors' drawings, after Barnes 2009: fol. 21r)

\section{Pentagon Construction of Mathes Roriczer's Geometria Deutsch (No. 2 in Table 1)}

The method published by the German master Mathes Roritzer, in his booklet from the end of the 15th century, is quite different from the other pentagonal draftings from medieval sources in a number of significant points. The method is widely known as that suggested by the famous artist Albrecht Dürer, in his 1525 book "Underweysung der Messung, mit dem Zirckel und Richtscheyt". Although there is no direct reference to Roritzer's work in Dürer's booklet, it is most likely that he knew of the method from Geometria Deutsch. The actual origin, however, is still obscure. Among the methods represented in medieval sources, this is the only approximation that is commented on by obvious textual instructions, which exclude any modern misunderstandings concerning the steps; despite this, researchers of the topic have failed to detect any coherent mathematical idea in the background. Unlike the method in the previous chapter or those of Hans Hammer or the Vienna Collection of Prints and Drawings, that all followed some detectable logic, the two crucial lines (FC, GD) in Roriczer's drafting, tracing out the points $\mathrm{C}$ and $\mathrm{D}$ of the pentagon, seem a stroke of genius (Fig. 2) was it invented by accident or did it result from the high standard of mathematical knowledge of the architects of the Prague lodge; it certainly highlights the creative mind of medieval master masons. As an important feature of the drafting, Roriczer has expressed that the whole pentagon could be constructed from the first step to the last by the same opening of the compass, which also makes it favourable for practical use. 'Wer ain funff ort reissen wil mit vnvēruckteñ zirkel So tue dē czirkel auf als weit du ain feldūg habn̄ wild vn̄ mach czwen puchstabn.a: :b. des ain figur' (Shelby 1977: 115-118; Sódor 1982: 386-387). 
Fig. 2 Roriczer's method with the two crucial lines (FC and DG) (authors' drawing)

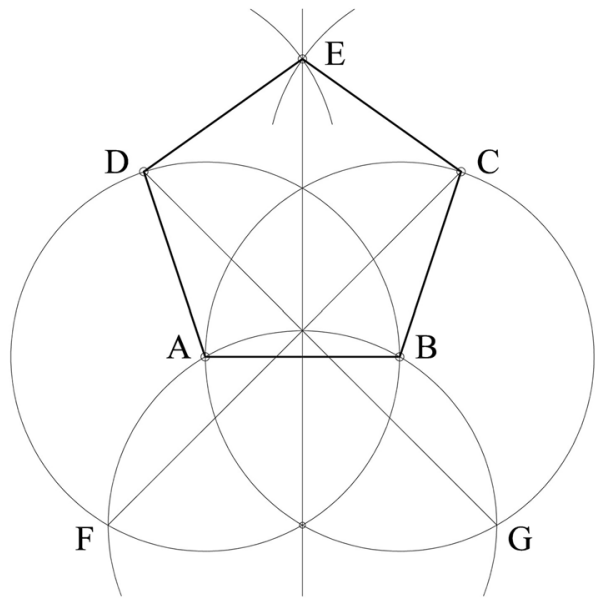

\section{Diagram A of the Vienna Collection of Prints and Drawings-Pentagon Approximation from Above and Below (No. 3 in Table 1)}

The clue for the pentagonal diagram in sheet no. 17079 (Fig. 3a after Böker 2005: 396) of the Collection of Prints and Drawings of the Academy of Fine Arts, Vienna (Koepf 1969; Böker 2005; Hoppe 1995: 146-149) has been published by Meckseper, who discovered that the logic of the construction had been to seek the proper position of point $\mathrm{E}$ for the regular pentagon somewhere between the edge of the pentagon with the blunt angle $\left(E^{\prime}\right)$ and the edge of the one with the sharp
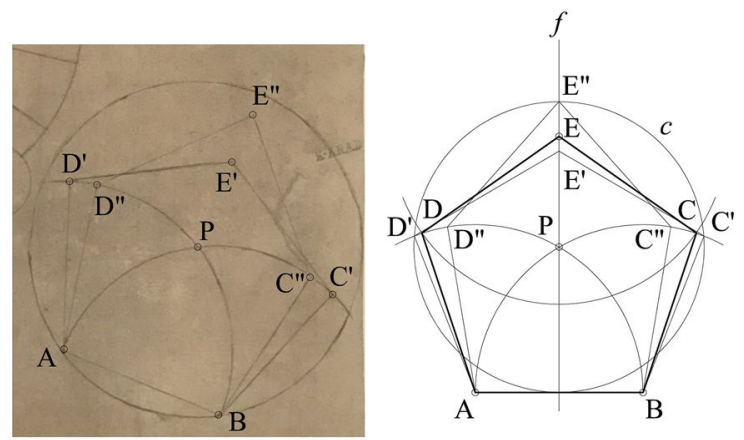

(b)

(a)
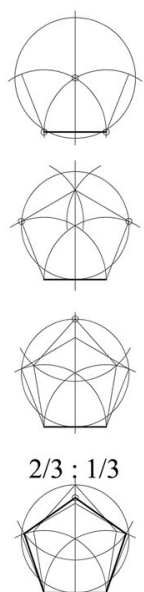

Denotes:

$a$ : length of the side of the pentagon,

$d(A, B):$ distance between $\mathrm{A}$ and $\mathrm{B}$,

$c(O, r)$ : circle with center $O$, radius $r$,

Put $d(A, B)=a$ !

$P:=c(A, a) \cap c(B, a)$,

$f$ is perpendicular to a line segment $\overline{A B}$.

$m:=d(P, \overline{A B})$,

$C^{\prime}:=c(P, m) \cap c(B, a)$,

$D^{\prime}:=c(P, m) \cap c(A, a)$,

$E^{\prime}:=c\left(C^{\prime}, a\right) \cap c\left(D^{\prime}, a\right)$

$E^{\prime \prime}:=f \cap c(P, m)$,

$C^{\prime \prime}:=c\left(E^{\prime \prime}, a\right) \cap c(B, a)$,

$D^{\prime \prime:=} c\left(E^{\prime \prime}, a\right) \cap c(A, a)$.

$2 d\left(E^{\prime}, E\right)=d\left(E, E^{\prime \prime}\right)$.

$C:=c(B, a) \cap c(E, a)$,

$D:=c(A, a) \cap c(E, a)$.

(c)

(d)

Fig. 3 a Original image of diagram a from the Vienna collection of prints and drawings with its clues as suggested by Meckseper: b overview, c steps and d denotes of the construction (authors' drawings after Böker 2005: 396) 
angle ( $\left.E^{\prime \prime}\right)$ (Meckseper 1983: 38). However, the most obscure point of the operation, namely the practical calculations and the final drawing is still quite unanswered as no original blind lines can confirm the steps and the 1/3:2/3 division suggested by Meckseper (Fig. 3b-d). Conversely, the figure is so sketchy that it is also questionable whether the author's original intentions would have been an accurate geometrical construction.

\section{Diagram B of the Vienna Collection of Prints and Drawings (No. 4 in Table 1)}

Hoppe described one of the figures of sheet no. 16963 (Koepf 1969: Fig. 148, Böker 2005: 277) as another sketch for a pentagon approximation providing a proper hypothesis for its steps (Hoppe 1995: 153-155). Accepting that the first steps (creating the circles of a radius equal to the side of the pentagon in order to find the proper point $\mathrm{D}$ and $\mathrm{C}$ of the pentagon) can initiate a pentagonal construction, but the upper point $(E)$ is so high that the result is probably too far from a quasiregular pentagon. Thus, the purpose of the drawing — suggested by Hoppe-is rather doubtful (Fehér et al. 2018a, b; Pentagons: 298) (Fig. 4).

\section{Diagram C of the Vienna Collection of Prints and Drawings (No. 5 in Table 1)}

Similar to diagram $B$, the original purpose of this figure, in sheet no. 16935 verso (Fig. 5a), is also a curious point of any interpretation. The idea that it could be a pentagon has been published by Johan Böker, referring to Dominic Boulerice without any explanation or citation of the latter's publications (Böker 2005: 256-257). As the drawing of two circles and curves, without any lines recalling any features of a pentagon, is right next to a plan of a lierne vault, it obviously can be considered as an auxiliary drawing for lifting the arches of the vault into the third dimension (Fig. 5b, c). However, the line segment suggested by Boulerice, in his analytical drawing, as the actual outcome of the construction process is convincingly close to the length of a regular pentagon inscribable into the original circle. If

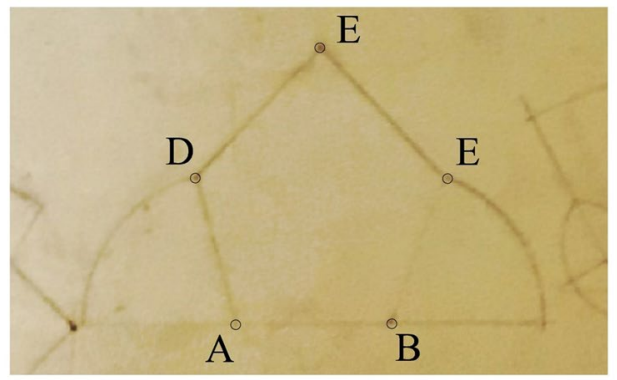

(a)

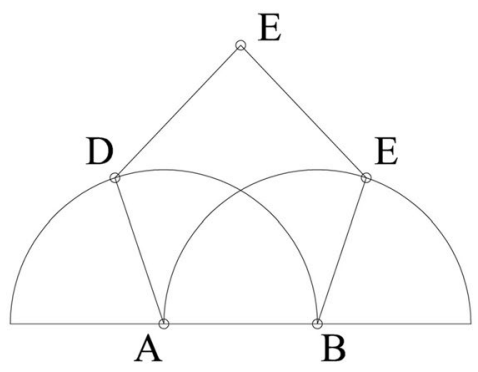

(b)

Fig. 4 a Original image and b redrawn version of Diagram B of the Vienna collection of prints and drawings (authors' drawings after Böker 2005: 277) 


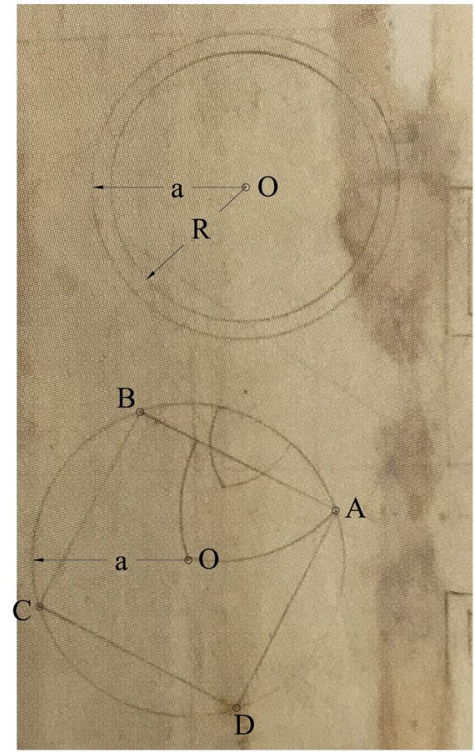

(a)

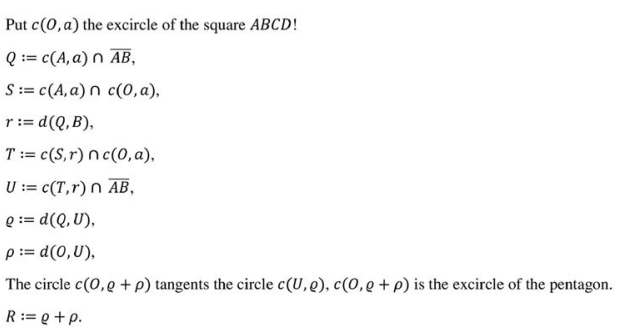

(b)
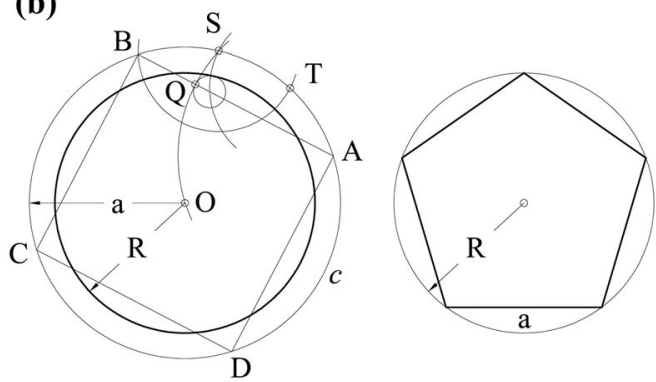

(c)

Fig. 5 a Original image of diagram $\mathrm{C}$ of the Vienna collection of prints and drawings and its clue suggested by Boulerice: b denotes and c explanation of the construction (authors' drawings after Böker 2005: 256-257)

Boulerice's interpretation is correct, this drawing would be of significant importance being the only construction known from medieval sources that derive the radius of the circumcircle of a regular pentagon using the length of the sides as input data.

\section{Pentagonal Construction in the Sketchbook of Hans Hammer (No. 6 in Table 1)}

The construction of the German master of Strasbourg Cathedral in the last third of the 15th century, (Fig. 6a) follows the principle of the division of the perimeter of a circle into five parts applying a string 5/4 the length of the radius (Hoppe 1995: 150-153) (Fig. 6c). According to the modern mathematical proof, the method applies an approximation of $\pi$ as $25 / 8$. Although we cannot be sure that Hans Hammer used this coincidence intentionally, it is worth mentioning that the same mathematical speculation for the relation between the radius and the perimeter of the circle had already occurred in ancient Babylonia (Borwein et al. 1997: 1-14). It is important to notice that the actual drawing in the sketchbook is a combination of multiple tracing methods, including the construction of a regular pentagon and a regular hexagon, while some additional lines and curves are of uncertain purpose as they do not belong to the construction of either polygon (cf. Reynolds 2001). To help the interpretation, the elements belonging to the pentagon construction are emphasised on the following figure (Fig. 6b). However, the context of the pentagon 


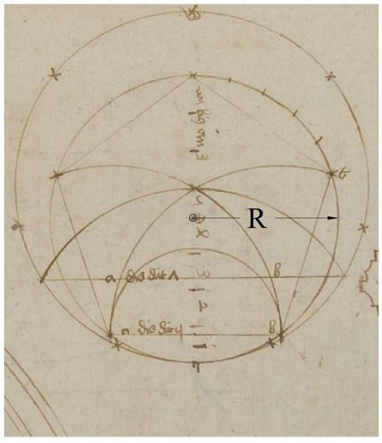

(a)

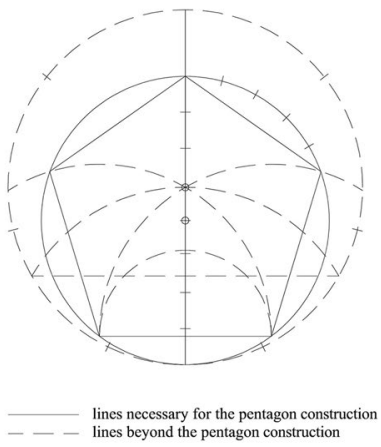

(b)

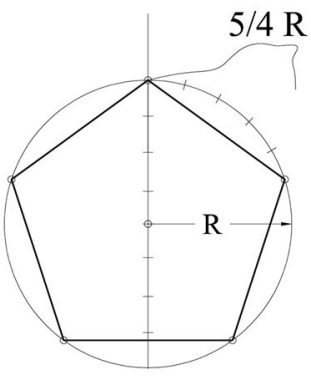

(c)

Fig. 6 a Original and b redrawn pentagonal diagram in Hans Hammers's sketchbook and $\mathbf{c}$ its clues as suggested by Hoppe (authors' drawings)

construction in Hammer's sketchbook is important to understand the possible application of this method, as this will be discussed later (Fig. 12).

\section{Pentagon in the Sketchbook of Master WG (No. 7 in Table 1)}

An interesting pair of drawings with a regular pentagon appears in the Frankfurt Lodge Book of Master WG on folio 18 (Fig. 7a after Bucher 1979: 219). Even though the authors of the present study are not convinced that this drawing represents a construction method for the pentagon, consideration should be given to

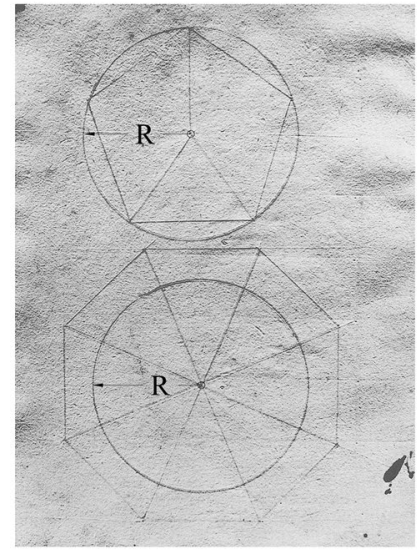

(a)

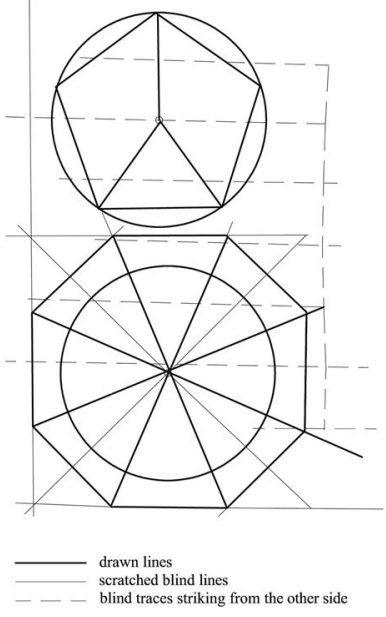

(b)

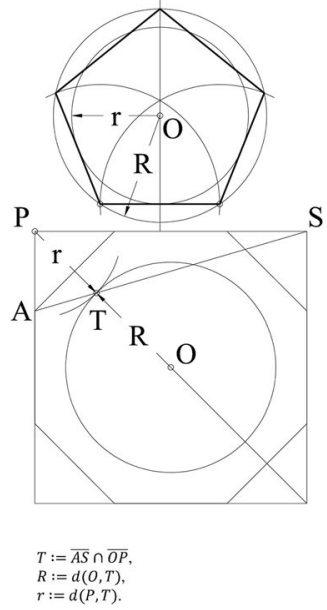

(c)

Fig. 7 a Original image of Master WG's lodgebook, b its redrawn version with blind lines scratched in the paper, the ink lines and the traces striking from the other side, and c the clue suggested by Hoppe (authors' drawings) 
the interpretation of László Hoppe from a mathematical point of view. His evidence was based on the octagon drawn below; the pentagon inscribed in a circle. According to the interpretation, the circle inside the octagon would divide the half diagonal of the square in the ratio of the radius of the incircle $(r)$ and the circumcircle $(R)$ of the pentagon (Hoppe 1995: 148-151) (Fig. 7c). The indispensable line that would set out the perimeter point of the circle inside the octagon is missing from the original drawing (Fig. 7b). In Fehér et al. 2018a, b; Pentagons: 300-303, a more detailed computation of the pentagon was published. This revealed that the level of inaccuracy of the construction was so significant that it is unlikely it could have been applied in practice. The distortion of the pentagon worked out by Hoppe's construction is so large, that his interpretation can be considered as imaginative (Fehér et al. 2018a, b; Pentagons: 300-303).

\section{8-10 Further Speculative Methods (No. 8-10 in Table 1)}

As the correct construction of the regular pentagon edited by Euclid in the Elements (Fig. 8a) is based on the Golden Ratio, additional approximations can be imagined applying neighbouring elements of the Fibonacci sequence (Hoppe 1995: 154-161). Leonardo Pisano (Fibonacci) published Liber Abaci containing the sequence in 1202 , but there is no direct evidence of his work having been known or applied by medieval architects in their designs (Fehér et al. 2018a, b; Golden Ratio: 37-38). Thus, the methods where the proportion 5:8 is used for calculating the side of the

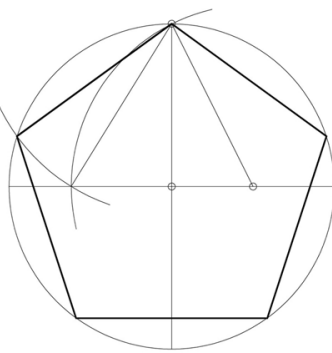

(a)

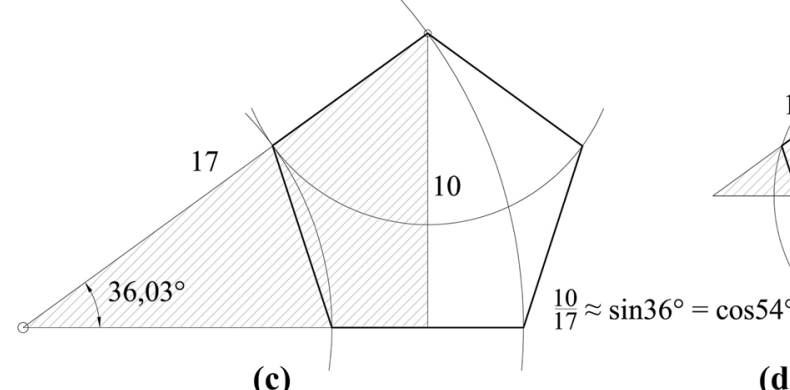

(c)

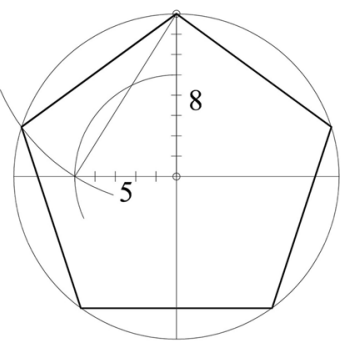

(b)

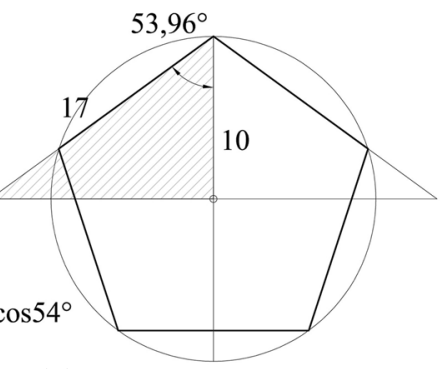

(d)

Fig. 8 a The correct pentagon construction of Euclid and b-d speculative methods using different numerical ratios (authors' drawings) 
pentagon from the radius of the circumcircle (no. 8 in Table 1, Fig. 8b) is speculative without any certainty regarding their medieval application. (The accuracy of the approximation can be increased by using other neighbouring pairs from the sequence, such as 8:13 or 13:21). Nonetheless, it should be noted that even Euclid's Elements were several times copied and translated in Western Europe or imported from the East (Scriba et al. 2015: 61-65, Corry 2013) throughout the whole Middle Ages, but no sign of the architectural application of the mathematically correct construction of the regular pentagon can be detected.

The numerical ratio of 10 and 17 can also be applied to speculative methods, as this proportion approaches the sine $36^{\circ}$ and the cosine $54^{\circ}$ (Fig. 7). The first method is based on a right-angled triangle for which the ratio of the shorter cathetus to the hypotenuse equals 10:17. The side length of the pentagon can be determined by elongating the longer cathetus to 17 moduls (no. 10 in Table 1, Fig. 8c). In the other method, the angle of $53.96^{\circ}$ can determine the direction of the two upper sides of the pentagon inscribable in a circle (no. 9 in Table 1, Fig. 8d). The significance of the 10:17 ratio was also emphasised by Peter Kidson, who proposed that medieval architects could easily have solved pentagonal situations if they had been aware that the proportion of the side length and the diameter of the circumcircle also approaches 10:17. (Kidson 2008: 11-13).

\section{Mathematical Analysis and Comparison of the Methods}

All these approximations, from different medieval sketchbooks and architectural plans, are evidence highlighting the practical and inventive mind of master masons. The transfer of knowledge between architects in the Middle Ages is extremely hard to confirm, but the suspicion that they did not apply the correct construction of the regular pentagon even if they were aware of the actual method, shows that, crucially, their intention was rather its utilisation in the actual architectural situation than the regularity or the accuracy. The paper's mathematical analysis accentuates the different features of all these methods. In the following table (Table 1) the accuracy of the resulting pentagons is compared by the examination of their angles, the ratio of the length of their sides, and their circumcircle. According to the latter factor, the methods are sorted into three groups.

In Table 1, the results of calculations regarding the accuracy of the mentioned approximate constructions are listed; a detailed presentation of all the mathematical calculations behind the results is outside the framework of the current paper. As a reference, the first row in the table provides the data for a correct regular pentagon for comparison with the approximations given. The construction methods are subdivided into three groups. In the first group, the approximate solutions do not require a circumcircle, as their initial data tend to be the side length. The second group consists of those methods for which a circumscribed circle has been given. In these cases, the central angle belonging to the sides can also be computed. Apart from these two groups, at the end of the table, we examine Hans Hammers approximation method that cannot be performed in the Euclidian way using just ruler and compass. In each group, the 
particular solutions are ranked according to the accurateness of angles starting with the closest to regular. In order to detect the accurateness of the methods, a comparison of the angles is more characteristic than the side lengths, because a pentagon of equal sides is not rigid, it can be deformed. Therefore, it is clear, that angle deviation is a better indicator; moreover, it can be calculated for all the constructions both with or without a circumscribed circle.

It is worth mentioning that in both group 1 and 2 , the best approximate constructions are those based on the ratio of 10:17 (no. 9 and 10 in Table 1). These hypothetical construction tools would provide very effective approximations for building a regular pentagon; however, no actual evidence of their application is mentioned in medieval sources. The second-best approximation in group 2 uses the Fibonacci numbers 5 and 8 (no. 8 in Table 1). In this, also speculative method, these lengths substitute $\frac{\sqrt{5-1}}{2}$ and 1 of the ideal solution. Although when using other consecutive members of the Fibonacci sequence, the accuracy can be increased, the presented construction is fairly close to the exact one and is significantly easier to construct. Thus, the best results are presented by speculative methods while the constructions based on original sources tend to be less accurate. As diagram $C$ of the Vienna Collection (no. 5 in Table 1) is performed with a relatively high number of circles, this was more challenging to compute. In this particular case, Wolfram Mathematica system has been used during the calculations. Ultimately, it can be concluded that the relatively complicated process produces rough approximation, which is probably because the last constructed side has to compensate the error of the whole construction. Master WG's pentagon (no. 7 in Table 1) is based on a square and a derived regular octagon. In this case, both the maximum deviation of sides and central angles are higher than those of the previous ones.

If the necessity of having a circumscribed circle in the construction is omitted, then a greater variety can be achieved with higher accuracy. This explains the better approximations of the sides except for diagram A of the Vienna Collection (no. 3 in Table 1) in the first group. In principle, the angle values are comparable to those of the first group; in most of the cases, they are better.

Both in Roriczer's construction (no. 2 in Table 1), which is very elegant using only circles of the same radius, and in diagram $B$ of the Vienna Collection (no. 4 in Table 1), all the sides are equal. In the case of the latter, the pentagon is a bit farther from the regular one, but it is derived from the same right-angled triangle as the construction in the sketchbook of Villard de Honnecourt. Diagram A of the Vienna Collection (no. 3 in Table 1), the less accurate member of group 1, aims to balance two pentagon constructions with two identical vertices in an "optimal way" by replacing the fifth vertex with the trisector of the two. This approximate solution is, however, far from optimal.

Hans Hammer's method, the exceptional case of group 3, is quite accurate as it is the third in the angle deviation ranking. The point of the observation is that the central angle of each side of a regular pentagon is $\frac{2 \pi}{5}$, which is close to $\frac{5}{4}$. However, this is not a classical construction because measuring $\frac{5}{4}$ radian to the circumference of a circle cannot be exactly solved by the traditional ruler and compass method.

It can be seen that the accuracy of the pentagonal approximations is quite poor and imprecise. However, in real scale and even on the drawing platform this is still 
negligible. The most inaccurate is the method of Villard, but it can also be imagined as being used for a tracing layout of a half decagonal apse, for example.

\section{Possible Architectural Applications of the Methods}

Knowing the geometrical logic behind particular regular pentagon constructions, it seems obvious to ask the question as to how these could have been applied to the design of actual structures. It must be stressed that the final form could differ slightly from the original concept as a result of the inaccuracy of the execution. Later modifications and renovations can also add to this divergence. Accordingly, taking the small margin of accuracy between the particular methods into consideration, it is apparent that the construction used in the design can hardly be determined by simply analysing the accuracy of a pentagon represented in certain structures. Also, an accurate survey of relevant medieval architectural features is not always available for comparison.

Besides their mathematical features, the geometric character of the regular pentagon approximations, namely the initial data and the principle of the construction, can determine the type of architectural situation in which they could have been applied. Furthermore, in most cases, the author or the circle of the possible author and the period in which the drawing arose, can help ascertain the scope of relevant monuments to be associated with certain approximations. If available, the master's original pentagonal plans can be regarded as the most direct application of their method. Therefore, these should be given special consideration during any analysis.

As Carl F. Barnes, the author of the latest facsimile of the portfolio of Villard de Honnecourt has claimed, "no building anywhere can be securely attributed to Villard' (Barnes 2009: 218). In addition, it is also uncertain as to whom the pentagonal tower drawing (no. 1 in Table 1) can be attributed, considering that Hand IV has copied a formerly existing figure from folio 20 verso; however, the drawing was without doubt created in Northern France in the second half of the 13th century. Villard surely visited the construction of the Cathedral of Reims and other newly built Gothic cathedrals of the era, (Barnes 2009: 220-227) where several architectural appearances of the pentagon can be mentioned. For instance, in the Cathedral of Reims and Laon, there are tracery windows of five-petalled parts, and the choir of Reims has been designed with a half decagon. Nancy Wu has also identified a pentagon in her theoretical reconstruction for the geometrical layout of the plan of Reims Cathedral (Wu 2002: 165). In accordance with Barnes, no operation can be attributed to Villard in Reims; however, in the sketchbook, his drawing for the half-decagonal choir of the Cathedral of Meaux with the inscription 'vesci les ligement de le glize de miax de saint estienne '('See here the plan of the church of Saint Etienne at Meaux') (translated by Barnes 2009: 96) represents a direct example for the application of the pentagon (Fig. 9a).

The designers needed to inscribe five sides into the semi-circle of the apse. The initial data of the pentagonal approximation in folio 21 recto, technically, has been the side length, but the method based on the angles could have been 


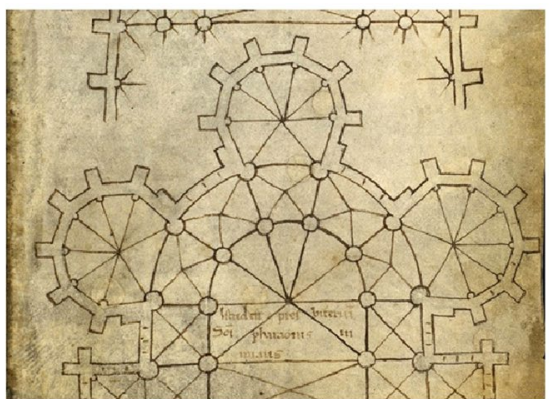

(a)

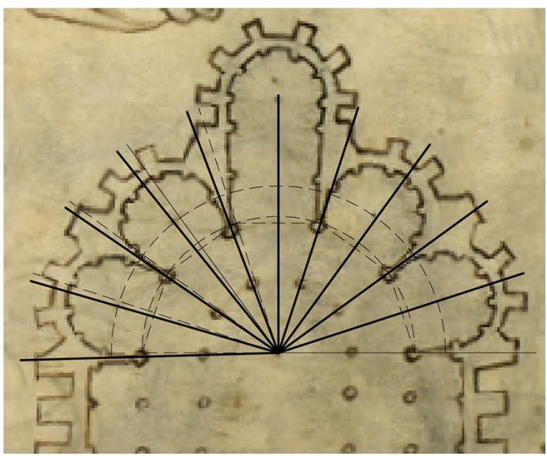

(d)

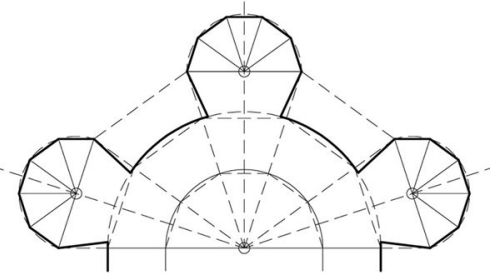

(b)

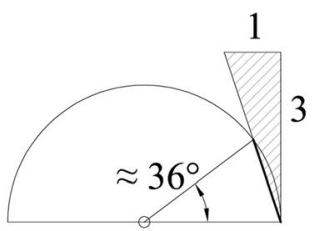

(c)

(e)

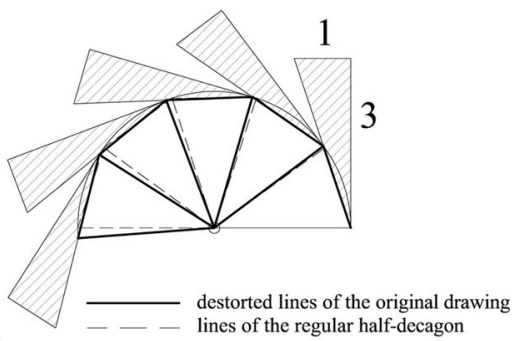

Fig. 9 Drawing of Meaux cathedral in Villard's sketchbook a in the original form, $\mathbf{b}$ the redrawn system, and $\mathbf{c}$ the idea of the construction with the 1:3 ratio. d Drawing of Cambrai Cathedral with Bork's observation about the distorted geometry with e a possible reason for the inaccuracy (authors' drawings, Barnes 2009: fol. 14v, 15r, Bork 2011: 33)

easily adapted to a situation where the circumcircle was determined (Fig. 9b, c). The 1 to 3 ratio is entirely appropriate for tracing out the direction of the first side, and then, by rotating the angle, starting from both sides to meet in the middle, the complete half-decagon can be constructed. Jean Wirth suggested a parallel solution for the construction of this choir plan, using right triangles of sides of 3, 4 and 5 to approximate $36^{\circ}$ (Wirth 2015: 127-128). A similar method has been described by Josep L. Ginovart and his colleagues concerning the heptagonal (half-tetradecagon) choir of the Cathedral of Tortosa in the Traça of Guarc. (Ginovart et al. 2013). Robert Bork recognised that in the case of Villard's drawing of Cambrai Cathedral (folio 14 verso), the distortion of the half-decagon of the choir was larger on the left side than on the right side (Fig. 9d) Bork 2011: 32-33). Perhaps the reason for this inaccuracy is just the sketchy nature of the drawing; this could have resulted in the method of the construction. If the 1 to 3 ratio had been used from the right side of the hemicycle, the distortion of the half-decagon grew from right to left (Fig. 9e). 
It is important to note that the half-decagonal apse was quite common in the major part of the Middle Ages (Feher et al. 2018a, b; Pentagons: 309-311). Lisa Schürenberg has considered this layout as a separate group within French Gothic architecture (Schürenberg 1934: 31-62; Kuthan et al. 2016: 77). In the Cathedral of Prague, the half-decagonal apse (Fig. 10d) was designed by Matthias of Arras, the previous master to Peter Parler, in the mid-14th century; he was also of Northern French origin and had worked in Avignon previously (Kuthan et al. 2016: 79). Without suggesting a direct link between Villard's portfolio and the choir of the cathedral of Prague, it is obvious that several examples of similar choirs from all over Europe suggest the problems of constructing the halfdecagon often emerged, and a method similar to the one presented in Villard's portfolio could offer a useful solution. Jiří Kuthan and Jan Royt have considered this type as a modern appearance in Prague (Kuthan et al. 2016: 79), but the shape had already occurred centuries earlier not only in Villard's age but also, for instance, in Kalocsa (Hungary) (Marosi 2000; Szakács 2019) or Southern France in the 12 th century.

Concerning the pentagon construction published in the Geometria Deutsch (no. 2 in Table 1, Fig. 10 a), it is important to point out that both Mathes Roriczer and his probable fellow lodger, Hans Schmuttermayer, have emphasised in their books on pinnacles that their knowledge had been inherited from the 'Junkers of Prague' ('dj iungkherrn von prage' and 'die Junckhern von prage' Shelby 1977: $82,126)$, that are generally identified as the Parlers. This century-long transfer of knowledge on pentagon drafting is of great significance. Lon R. Shelby has proposed that the link between the Prague masters and the Roriczer family could have been Wenzel Roriczer, Mathes's grandfather, who had worked with the Parler lodge of the Saint Vitus Cathedral in the second decade of the 15th century (Shelby 1977: 7-8). There is no clear evidence, however, proving that the 'Junkers' could have been identified with the Parlers, rather than any other masters of the Prague lodge (Legner 1978: 7). What is certain, is that after the activity of Peter Parler, several members of the next Parler generation (for instance, Johann, Wenzel, Janco or Michael) worked in Prague or other parts of Bohemia, such as Kutna Hora or Kolín (Legner 1978:11; Marosi 1997: 149-152).

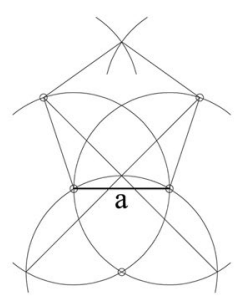

(a)

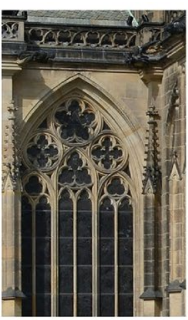

(b)

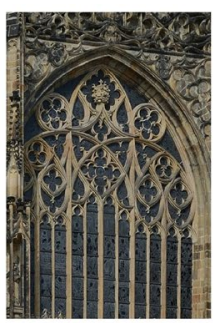

(c)

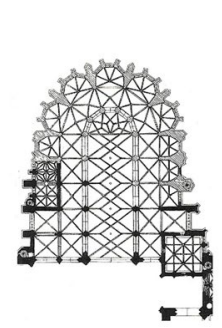

(d)

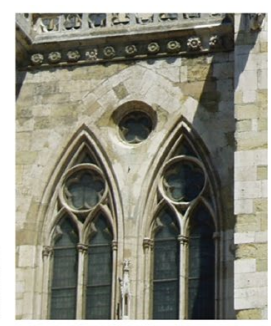

(e)

Fig. 10 a Roriczer's pentagon approximation, $\mathbf{b}$, $\mathbf{c}$ pentagonal traceries and $\mathbf{d}$ the plan of the Cathedral of Prague, e five-petaled traceries of the Cathedral of Regensburg (authors' drawing and photo, Kuthan et al. 2016) 
Whether the 'Junkers' were, in reality, the Parlers, it is sure that the examples, comparable to Roriczer's pentagon construction, range from mid 14th-century Bohemia to late 15th-century Germany. Peter Parler probably studied in Cologne and previously worked on the Frauenkirche of Nuremberg before his arrival to Prague in 1356 (Kuthan et al. 2016: 87). He took over the operation of Saint Vitus Cathedral with the finished ambulatory of the half-decagonal choir designed by Matthias of Arras. Throughout the construction, several pentagonal tracery windows of five-petalled sections can be found, such as those of the eastern window of the southern transept (Kuthan et al. 2016: 127); the upper part of the pillars of the flying buttresses of the eastern choir; (Kuthan et al. 2016: 230) the western façade (Kuthan et al. 2016: 433) and the tracery composition above the portal of the southern transept vestibule built in 1367 (Fig. 10b, c) (Kuthan et al. 2016: 113, 133-134, 136-137, 238). In case of the southern facade of the ground floor of the Great Tower, it is significant that both the present form rebuilt by Josef Mocker in the 19th century and the original plans, conserved in the Vienna Collection of Prints and Drawings contain pentagonal parts (Kuthan et al. 2016: 133, 139, 142, 152, 242). While the half-decagonal apse was Arras's design, an identical geometrical assignment is mentioned in Parler's works in an entirely different architectural situation: the semi-circular lunette of the northern portal of the Saint Wenceslas Chapel decorated with five petals (Kuthan et al. 2016: 105).

With regard to the Roriczer family, the construction of the Cathedral of Nuremberg was directed by Konrad Roriczer with the assistance of his son Mathes, and it is also likely that a century earlier Peter Parler had been there. Mathes also worked in Regensburg, where pentagonal window traceries can be found; (Fig. 10e) although, neither the churches of Nuremberg nor those of Regensburg have been designed with half-decagonal apses.

The frequent application of the pentagon in tracery windows, however, can hardly be associated with the method Roriczer has published and dedicated to his Prague predecessors. While the initial data of this approximation is clearly the side length of the pentagon, for a five-petalled form, the circumcircle should be determined first, especially in a complex composition of traceries where the role of this particular form is subsidiary. Roriczer's pentagon construction is inappropriate for such designs (Fig. 9). Hence, the question of the real application remains open; it also likely that both the Parlers and the Roriczers were aware of other pentagon approximations for the design of five-petalled forms.

The initial data of diagram A and B of the Vienna Collection of Prints and Drawings (no. 3 and 4 in Table 1) is the side of the pentagon. While diagram A of sheet no. 17079 is clearly a sketch for a pentagon approximation, the purpose of diagram B is much more uncertain. As the spine of the pentagon is far too high, it is doubtful that this diagram has been referred to as a pentagon. Concerning the architectural examples where diagram A (Fig. 11a) could have been applied, window traceries of Saint Stephan Cathedral of Vienna should be mentioned, but they raise the same contradiction as in the case of Roriczer's method (Fig. 11c). However, the collection of prints and drawings contain some ideal plans embracing pentagons, providing the most direct examples of a probable application of the method represented by diagram A. On sheet no. 16889, in the ideal plan of a gothic 

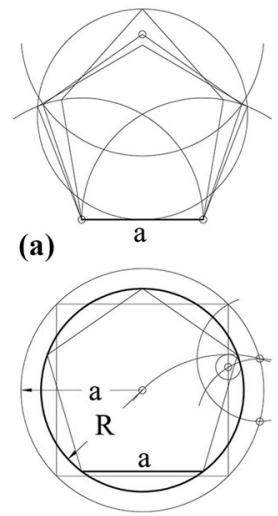

(b)

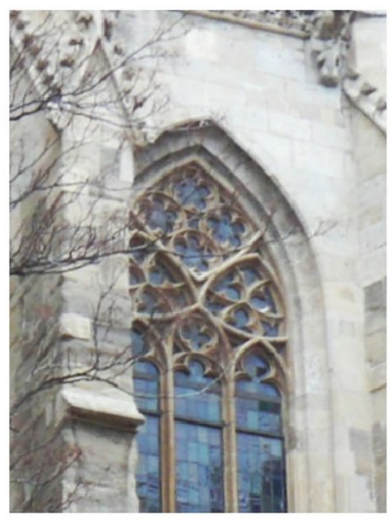

(c)

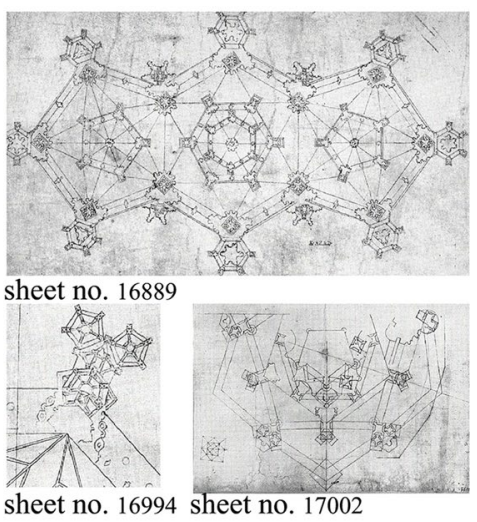

(d)

Fig. 11 Methods based on a diagram A and b Diagram C of the Vienna Collection, $\mathbf{c}$ tracery parts of the Cathedral of Vienna and d ideal Gothic plans of the Vienna Collection (authors' drawings, photo, Koepf 1969: Fig. 247, 368, 378)

baldachin, two lateral pentagonal bays are attached to a central hexagon (Fig. 11d) (Böker 2005: 200, Koepf 1969: Fig. 247). In this composition, it is entirely clear that the side of the hexagon has provided the initial data for the construction of the pentagons; thus, the method of diagram A could have been appropriate. The figures from sheets no. 16994 and no. 17002 (Böker 2005: 304, 314, Koepf 1969: Figs. 368, 378) are similar cases as far as the starting point of the construction is concerned. In the former, the pentagons of the small additional baldachins join to one side of a buttress of determined length, while in the latter, a system of rotated pentagons is presented in which the whole composition is based on a pentagon, so any data could have been fixed arbitrarily (Fig. 11d).

In the case of Diagram $\mathrm{C}$ of the Vienna Collection of Prints and Drawings (no. 5 in Table 1), where the crucial lines of Boulerice's suspicions are missing from the original drawing, it is doubtful if it is a pentagon approximation. However, it is quite confusing that the resulting pentagon is astonishingly accurate. Moreover, as a practical application, this construction could have been extremely useful for medieval architects as this is the only one where the circumcircle can be constructed directly from the side length. If this series of almost ad hoc steps had been a pentagon construction, it could have been applied both in the plan design of pentagonal buildings and in tracery works; although, in the case of the latter, it is not logical that the circumcircle could be constructed indirectly (Fig. 10).

In case of the figure on folio 18 of the Frankfurt Lodge Book of Master WG (no. 7 in Table 1), it is clear that the author's initial intention could hardly be a pentagon construction to be applied in architectural design. The mathematical analysis has also revealed that the inaccuracy is highly significant. The starting point of the evidence, as speculated by Hoppe (1995: 148-151) is a square with an inscribed octagon, but neither the side nor the radius of the inner circle or circumcircle of these figures has any connection to those of the eventual pentagon. The radius of the 
inner circle and a quasi-circumcircle of the pentagon appears in a rather accidental way. Beyond that, it is rather hard to imagine any architectural features where an octagonal form should be linked to a pentagonal one, which also suggests that the link between the two figures of folio 18 is undoubtedly questionable.

Hans Hammer's pentagon construction (no. 6 in Table 1) is the only one among the approximations occurring in medieval sources that needs the circumcircle as the initial data and follows the logic of dividing the perimeter of the circle into five parts. Thus, this method would certainly be appropriate for the design of the rather common five-petalled forms in tracery windows. Hammer's career, although he has noted some autobiographical data in his sketchbook, (Entz 1992; Fuchs 1992) is rather obscure, except for some personal information and the fact that he became the master of the Cathedral of Strasbourg in 1482. ('1482 vff die Paffen Fasznacht da wart ich Pallier' Fuchs 1992: 11, 13) The great western rose window of the cathedral contains pentagonal parts, but both the original plan conserved in the Vienna collection and the realised version can be attributed to Michael von Gmünd from the Parler family, (Marosi 1997: 151) and no other pentagonal building elements can be attributed to Hammer himself. The most direct application of his method can be found in his sketchbook, right next to the pentagonal figure, which also sheds light on the purpose of some blind lines of the drawing that have not yet been solved (Fig. 12a). The curves AD, BE, CF and CD are not related strictly to

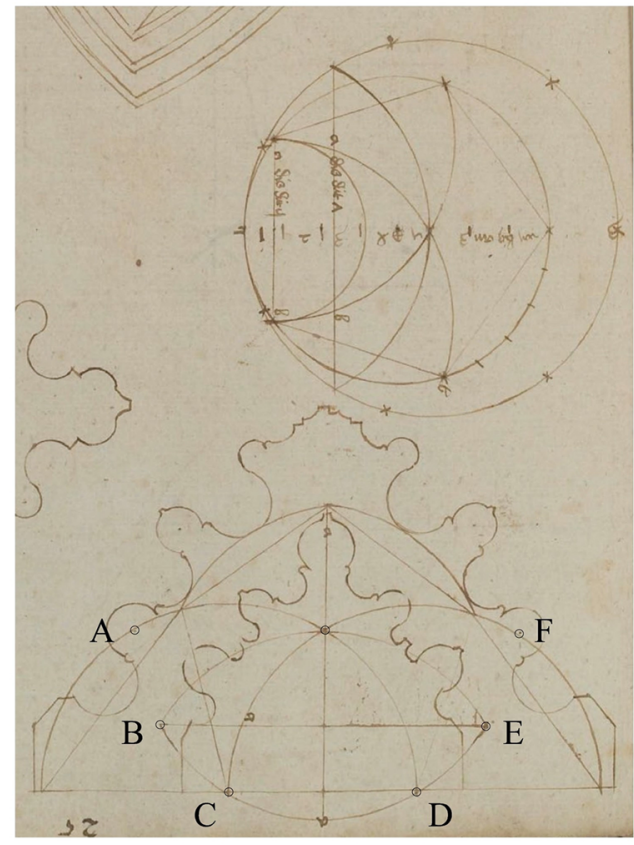

(b)

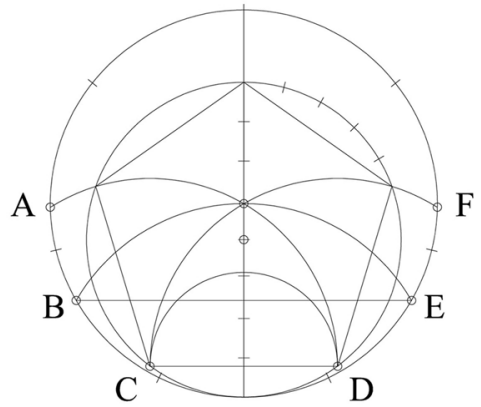

(a)

Fig. 12 a The diagram of profiles next to Hans Hammer's pentagon construction and $\mathbf{b}$ the redrawn version of the pentagon construction, indicating their connection between the two drawings (authors' drawings after http://diglib.hab.de/mss/114-1-extrav/start.htm?image=00041) 
either the pentagon or the heptagon construction, as both can be traced with the radii of the circumcircles (Fig. 12b). The curves and the segment BE can be explained in the context of the figure next to the pentagon, representing the construction of the profile of a great portal jamb and a rib of the vault (Fig. 12a after http://digli b.hab.de/mss/114-1-extrav/start.htm?image=00041). The pentagon of the previous figure, with its blind lines, plays a role in the geometry of these profiles, (Fig. 12b) providing new information about the application of the pentagon and the design methods of medieval master masons. Hans Hammer's figures confirm that pentagons were also used in the design process of profile elements such as ribs, window sills and traceries, expanding the scope of the applied form from individual pentagonal or decagonal buildings, church choirs, gothic traceries and floor plans. (In the theme of plan design see Hiscock 2000; Hiscock 2002: 108-116 and Shortell 2002).

Beyond the architectural features that can be linked to the certain approximative methods for the construction of a regular pentagon, the following example shows that other constructions must have been invented by master masons to solve more complicated geometrical problems. The late gothic tower of the Church of the Poor Clares in Bratislava, with a pentagonal plan, was added to the former 13th-century nave in the 15th century. Being an additional construction attached to an existing one, multiple data were determined for the geometrical layout of the pentagon (Fig. 13). Both the height and position of the perpendicular cord of the pentagon

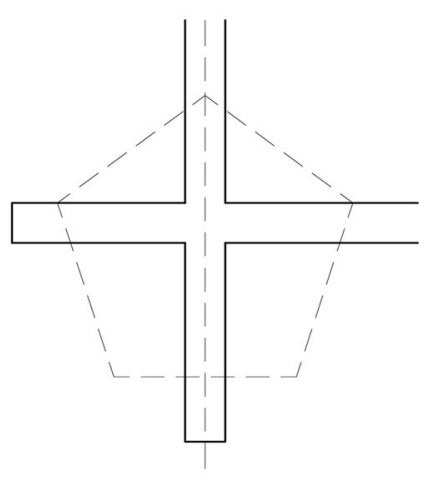

(a)

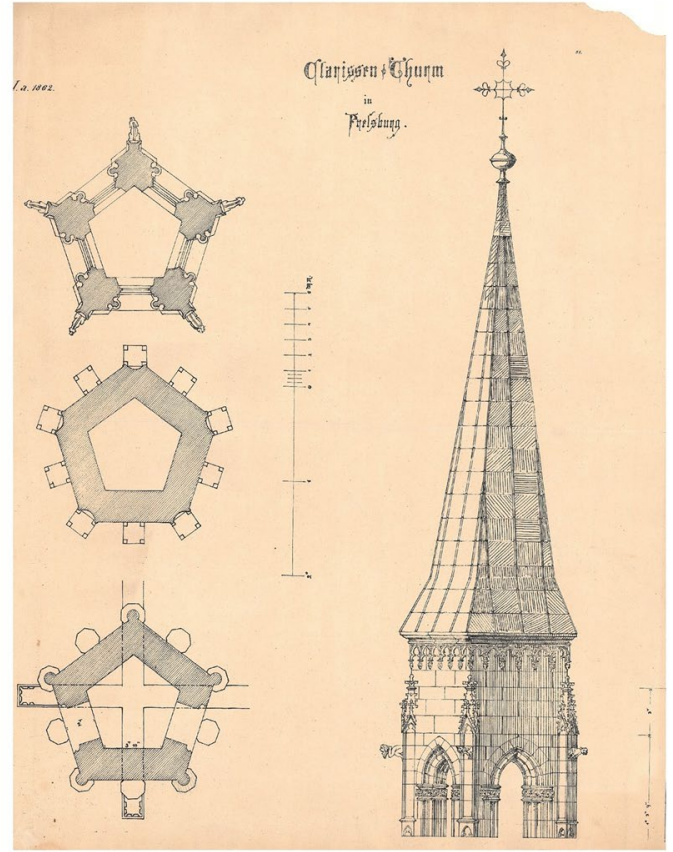

(b)

Fig. 13 a Schematic drawing of the design situation and b a 19th-century survey drawing of the tower of the Church of the Poor Clares in Bratislava (authors' drawing, Plan Collection and Archives of BME Department of History of Architecture and Monument Preservation, ref. no. 101161) 
were determined, although the dimensions of the pentagon depended on the master's decision. Finding the position of the centre of the circumcircle, or settling any points to result an appropriate pentagon, are all complicated operations demanding a high level of geometrical knowledge. The application of numerical ratios, such as 1:3 or 10:17 seems to be the simplest way to determine the angles of the sides. The construction can also be easily solved by drawing a pentagon of adequate dimensions on the planning table and positioning it to the angle of the existing walls; it is quite probable that a more complex construction could also be ascribed to the medieval master.

\section{Conclusion}

Even though the problem of the regular pentagon construction had been solved in Euclid's Elements, it seems to have been neglected in the practical work of architects in the Middle Ages, even though it was known among masters of the liberal arts. Searching for new construction methods consumed enormous intellectual power and produced various methods of varying accuracy. The reason for their appearance could be either a quest for a simple method convenient for practical use or the characteristics of certain tasks in architecture. This is one of the most beautiful examples from cultural history where creative geometrical thinking appeared in the works of architects rather than mathematicians.

It can be seen that pentagons were not uncommon in medieval design. Half decagonal apses, pentagonal traceries, and even design details were related to geometric methods based on the construction of a regular pentagon. It is plausible that this figure, besides the obvious square and triangle, was also used in plan design of monumental constructions such as the cathedrals of Reims and Saint Quentin.

This paper presents the calculations for the accuracy of each method known from medieval sources in terms of the sides and angles. Although certain approximative methods differ in their precision, the discrepancies are small enough to be ignored considering the accuracy of on-sight tracing as well as the building construction itself in medieval practice. The use of certain methods may have been determined by the tradition of particular workshops or regions, or as discussed in the case of the examples listed, the initial data of the construction. It should be noted that certain solutions may be adequate in cases where the diameter or radius of the circumscribed circle is given, or other cases where the length or even the position of a side of the pentagon is determined. For a clearer overview, the methods have been divided into different groups.

Through this analysis, not only is it possible to better understand the importance of the regular pentagon in medieval architecture, but also take a deeper look into the mathematical knowledge used in the design practice of medieval master masons.

Acknowledgements Open access funding provided by Budapest University of Technology and Economics (BME). The research was supported by the ÚNKP-18-3 New National Excellence Program of the Ministry of Human Capacities. 


\section{㭋 \\ EMBERI ERŐFORRÁSOK MINISZTÉRIUMA}

Open Access This article is distributed under the terms of the Creative Commons Attribution 4.0 International License (http://creativecommons.org/licenses/by/4.0/), which permits unrestricted use, distribution, and reproduction in any medium, provided you give appropriate credit to the original author(s) and the source, provide a link to the Creative Commons license, and indicate if changes were made.

\section{References}

Barnes, Carl F. 2009 The Portfolio of Villard de Honnecourt. A New Critical Edition and Color Facsimile. Ashgate.

Bechmann, Robert. 1991 Villard de Honnecourt. La pensée technique au XIIIe siècle et sa communication. Paris: Picard.

BÖKER, Johann Josef. 2005 Architektur der Gotik. Bestandskatalog der weltgrößten Sammlung an gotischen Baurissen (Legat Franz Jäger) im Kupferstichkabinett der Akademie der Bildenden Künste Wien; mit einem Anhang über die mittelalterlichen Bauzeichnungen im Wien Museum am Karlsplatz. Salzburg: Anton Pustet.

Bondurand, Édouard (ed. and tr.) 1887 Le Manuel de Dhuoda. Paris: Picard.

Bork, Robert. 2011 The Geometry of Creation. Architectural Drawing and the Dynamics of Gothic Design. Farnham: Ashgate.

Borwein, Jonathan, Borwein, Peter, Berggren, J. L. 1997 Pi: A Source Book. Springer.

Branner, Robert. 1960 Villard de Honnecourt, Archimedes, and Chartres. Journal of the Society of Architectural Historians, 19, 3 (1960): 91-96.

Bucher, François. 1979 Architector. The Lodge Books and Sketchbooks of Medieval Architects. Volume 1. New York: Arabis Books.

Corry, Leo. 2013 Geometry and arithmetic in the medieval traditions of Euclid's Elements: a view from Book II. Archive for History of Exact Sciences 67, 6 (November 2013): 637-705.

EnTz, Géza. 1992 Le séjour en Hongrie de Hans Hammer, futur maître d'œuvre de la cathédrale de Strasbourg. Bulletin de la Cathédrale de Strasbourg 20, (1992) 7-10.

Fehér, K., Halmos, B., Szilágyi, B. 2018 Pentagons in Medieval Architecture. Építés - Építészettudomány 46, 3-4 (2018): 291-318.

Fehér, K., Szilágyi, B., Halmos, B. 2018 Golden Ratio and Fibonacci sequence in Pentagonal Constructions of Medieval Architecture, Ybl Journal of Built Environment, 6, 1 (2018): 37-46.

FLetcher, Rachel. 2006 The Golden Section. Nexus Network Journal 8, 1 (Summer 2006): 67-89.

Fuchs, François J. 1992 Introduction au "Musterbuch" de Hans Hammer. Bulletin de la Cathédrale de Strasbourg 20, (1992) 11-70. 
Ginovart, Josep L., Anguera, Gerard F., Jover, Agustí C., De Sola-Morales Serra, Pau. 2013 Transfer of Mathematical Knowledge for Building Medieval Cathedrals. Nexus Network Journal 15, 2 (Summer 2013): 325-348.

Ginovart, Josep L., López-Piquer, Mónica, Urbano-Lorente, Judith. 2018 Transfer of Mathematical Knowledge for Building Medieval Cathedrals. Nexus Network Journal 20, 1 (Summer 2018): 153-172.

HaHnloser, Hans R. 1972 Villard de Honnecourt: kritische Gesamtausgabe des Bauhüttenbuches. Graz: Akademische Druck und Verlagsanstalt.

Hiscock, Nigel. 2000 The Wise Master Builder. Platonic Geometry in Plans of Medieval Abbeys and Cathedrals. Aldershot, Brookfield, Singapore, Sydney: Ashgate.

Hiscock, Nigel. 2002 A Schematic Plan for Norwich Cathedral. In: Wu, Nancy Y. (ed.) 2002 Ad Quadratum. The practical application of geometry in medieval architecture. Ashgate: 83-121.

Hoppe, László. 1995 Construction of the pentagon in the Middle Ages: Hans Hammer's pentagon construction. (In Hungarian) Építés- Építészettudomány 25, 1-2: 139-171.

KIDSON, Peter. 2008 Roriczer's Iceberg. Journal of the Warburg and Courtauld Institutes 71, (2008): 1-20.

KoEpF, Hans. 1969 Die gotischen Planrisse der wiener Sammlungen. Vienna, Cologne, Graz: Hermann Böhlaus Nachf.

Kuthan, Jiří, Royt, Jan. 2016 The Cathedral of St. Vitus at Prague Castle. Karolinum Press.

Legner, Anton. 1978 Die Parler und der schöne Stil: 1350-1400: europäische Kunst unter den Luxemburgern; ein Handbuch zur Ausstellung des Schnütgen-Museums in der Kunsthalle Köln II. Köln: Museen der Stadt Köln.

Marosi, Ernő. 1997 The Art of the Middle Ages II: 1250-1500. (In Hungarian) Corvina.

Marosi, Ernő. 2000 Some art historical questions of the second cathedral of Kalocsa. (In Hungarian) In: Koszta, László. 2000 About the history of Kalocsa. (In Hungarian) Kalocsa: Kalocsa Város Önkormányzata: 51-68.

MecksePER, Cord. 1983 Über die Fünfeckkonstruktion bei Villard de Honnecourt und im späteren Mittelalter. Architectura 13: 31-40.

MüLlER, Werner. 1990 Grundlagen gotischer Bautechnik. Ars sine scientia nihil. München: Deutscher Kunsverlag.

Reynolds, Mark A. 2001 From Pentagon to Heptagon: A Discovery on the Generation of the Regular Heptagon from the Equilateral Triangle and Pentagon. Nexus Network Journal 3, 2 (Autumn 2001): 139-146.

SCHÜRENBERG, Lisa 1934 Die kirchliche Baukunst in Frankreich zwischen 1270 und 1380. Berlin: Klinkhardt \& Biermann.

Scriba, Christoph J., SchreIBer, Peter. 20155000 Years of Geometry. Mathematics in History and Culture. Birkhäuser.

Shalby, Lon R. 1977 Gothic Design Techniques: The Fifteenth-Century Design Booklets of Mathes Roriczer and Hanns Schmuttermayer. Southern Illinois University Press.

Shortell, Ellen M. 2002 The Plan of Saint-Quintin: Pentagon and Square in the Genesis of High Gothic Design. In: Wu, Nancy Y. (ed.) 2002 Ad Quadratum. The practical application of geometry in medieval architecture. Ashgate: 123-148.

Sódor, Alajos. 1982 About Matthes Roriczer's books of 'Geometria Deutsch' and 'Wimpergbüchlein' (1486-1490) (In Hungarian). Építés- Építészettudomány 14, 3-4 (1982): 373-405.

SzAKÁCs, Béla Z. 2019 Ernő Foerk and the Medieval Cathedrals of Kalocsa. Ybl Journal of Built Environment 7 (2019) paper under review

WirTH, Jean. 2015 Villard de Honnecourt-Architecte du XIII siècle. Geneva: Libraire Droz S. A.

Wu, Nancy Y. 2002 The Hand of the Mind: The Ground Plan of Reims as a Case Study. In: Wu, Nancy Y. (ed.) 2002 Ad Quadratum. The practical application of geometry in medieval architecture. Ashgate: 149-168.

Publisher's Note Springer Nature remains neutral with regard to jurisdictional claims in published maps and institutional affiliations.

Krisztina Fehér is architect, $\mathrm{PhD}$ candidate and assistant lecturer of the Department of History of Architecture and Monument Preservation, Budapest University of Technology and Economics. Her PhD 
research topic is the geometric analysis of Gothic architectural profiled carved details in connection with medieval design methods. Her further research areas concern the methodology of manual and computer aided monument survey, research of historical monuments, and the analysis of archives from the history of architectural education.

Brigitta Szilágyi is mathematician, associate professor of the Department of Geometry in the Institute of Mathematics, Budapest University of Technology and Economics from 2012. Her research interests are differential geometry, in particular Finsler Geometry and homogeneous Riemann geometries Applications of mathematics to engineering and medical problems Nurturing talents in Mathematics. Homepage: www.math.bme.hu/ szilagyi.

Attila Bölcskei earned master degree at Eötvös Loránd University (Budapest), Faculty of Natural Sciences as teacher of Mathematics, Chemistry and Descriptive Geometry. Later he got PhD degree in Mathematical Sciences at Budapest University of Technology and Economics. Finally, he has habilitation in Architecture at University of Pécs (Hungary). He works as college professor at Szent István University, Ybl Miklós Faculty of Architecture and Civil Engineering. His special interests are Geometry in Architecture; Differential geometry, esp. homogeneous geometries; Algoritmical approach of tilings in various planes; Art and geometry; Teaching of geometry in higher education and Measurement of spatial ability with different tests.

Balázs Halmos is architect, assistant professor of the Department of History of Architecture and Monument Preservation, Budapest University of Technology and Economics. He is PhD in History of Architecture, has a postgraduate degree as Special Engineer in Preservation of Built Heritage. He is part time lecturer at University of Debrecen, Faculty of Engineering. His research interests are historical building research, building archaeology, proportions and geometric constructions in medieval and Renaissance architecture and the history of Renaissance and Baroque architecture. 